Global Business Research Congress, May 30-31, 2019, Istanbul, Turkey.

\title{
POSTPONING BANKRUPTCY AND DEBT RESTRUCTURING
}

\section{DOI: 10.17261/Pressacademia.2019.1105 \\ PAP-V.9-2019(52)-p.278-284}

\section{Gulay Demir ${ }^{1}$, Suat Teker ${ }^{2}$}

${ }^{1}$ Işık University, Graduate School of Social Sciences, Maslak Campus, Sariyer, İstanbul, Turkey. smmmgulayd@gmail.com, ORCID: 0000-0002-2654-8811

${ }^{2}$ Işık University, Maslak Campus, Sariyer, Istanbul, Turkey.

suat.teker@isikun.edu.tr, ORCID: 0000-0002-7981-3121

To cite this document

Demir, G., Teker, S., (2019). Postponing bankruptcy and debt restructuring. PressAcademia Procedia (PAP), V.9, p.278-284

Permemant link to this document: http://doi.org/10.17261/Pressacademia.2019.1105

Copyright: Published by PressAcademia and limited licenced re-use rights only.

\section{ABSTRACT}

Purpose- This paper intends to examine how a firm must be audited when filed a case for debt restructuring in order to protect the creditors, save the firm creating aconomic value and provide an assurance for the reports of auditing firms.

Methodology- Bankruptcy, debt restructuring and auditing process for the particular period are examined

Findings- There are limited number of firms in Turkey subject to external auditing. Due to economic crises, enexpected movements in exchange rates and insufficient amount of equity sources, firms are perforced to obtain loans form financial institutions. Later, these firms mosly demand debt restructuring to gain time to pay their loans over a longer period. It is viewed that most firms filed a debt restructuring has failed to obtain an extented periof from the court.

Conclusion- Reporting audited financial statements in complience with the standarts of accounting and auditing will partialy secure the firms to turns around the debt restructuring. In order to save the firms that filed a debt resturcturing, all firms should be external audited and a new regulation for writing checks should be worked on.
\end{abstract}

Keywords: Postponing bankcruptcy, debt restructuring, bankrupcy law, insolvency.

JEL Codes: K20, K22, K23

\section{IFLAS ERTELEME VE KONKORDATO}

\section{ÖZET}

Amaç- Bu çalışmada borca batık firmaların ekonomiye kazandırılması yönünde sağııkı adımlar atılabilmesi, alacaklı firmaları tahsilat aracı olarak aldıkları çeklerin, borçlu firmanın konkordato ilan etmesinden sonraki süreci ve Bağımsız Denetim Kuruluşlarınca hazırlanan raporların makul güvence verebilmesi için, firmanın nasıl bir denetime tabi tutulması gerektiği incelenmiştir.

Yöntem- İflas, kondordato ve dış denetim firmalarının yürüttükleri süreçler, iligli kanun ve standartlar çerçevesinde incelenmiştir.

Bulgular- Türkiye' de bağımsız denetime tabi şirket sınırlı sayıdadır. Firmaların özkaynak yetersizliği ile birlikte ekonomik dalgalanma, kur veya faiz riski karşısında banka veya diğer finans kuruluşlarına borçlanmaları kaçınılmaz olmakta ve ödemeler konusunda zaman kazanmak için konkordato talep edilmektedir. Bir çok konkordato talep eden firmaların akıbeti izlendiğinde ise, geçici süre sonrası kesin süreyi alamadığı gözlemlenmiştir.

Sonuç- Finansal tabloların tüm önemli yönleriyle finansal raporlama standartlarına uygun olarak hazırlanması, borca batıklıktan çıkış sürecinin güvencesini oluşturacaktır. Bağımsız Denetim Kuruluşlarınca hazırlanan raporların makul güvence verebilmesi için, firmanın tam bağımsız denetime tabi tutulması ve ticari hayatta vazgeçilmez ödeme aracı olarak kullanılan çek mevzuaatında gerekli düzenlemelerin yapılması, borca batık firmaların ekonomiye kazandırılması yönünde sağlıklı adımlar atılabilmesini sağlayacaktır.

Anahtar Kelimeler: Iflas erteleme, konkordato, iflas kanunu, ödeme güçsüzlüğü

JEL Kodları: K20, K22, K23 


\section{Giriş}

Ülkemizde Temmuz 2016 da ilan edilen OHAL uygulamasının ülkemiz üzerinde yarattığı güven ortamı ile beraber, 2018 yılının ikinci çeyrek dilimden sonar, döviz kurlarında meydana gelen yüksek dalgalanmalar, özsermeyeden ziyade kredi ile faaliylerini sürdüren ve döviz borçlanması olan firmaları olumsuz yönde etkilemiştir.

Borca batık yada mali açıdan zor duruma düşen borçlunun, içinde bulunduğu sıkıntılı durumdan ticari itibarını sarsmadan korunmasını amaçlayan ve alacaklıları ile yapılan bir anlaşma türü olan "konkordato uygulaması", 28.02 .2018 tarihli , 7101 Sayılı "Icra ve iflâs Kanunu ve Bazı Kanunlarda Değişiklik Yapılması Hakkında Kanun” ile yeniden düzenlenmiş ve iflas erteleme tamamen yürürlükten kaldırılmıştır. Dosya şekil şartının yerine getirilmesi ile geçici mület alan firmanın, kesin mühlet alabilmesi ise belirli şartlara bağlanmıştır. Bu şartların en önemlilerinden biri ise, borçlunun sunduğu iyileştirme projesinin ileriye dönük gerçekleşme durumumun yetkili kurumlarca denetiminin yapılarak rapora bağlanmasıdır.

Borçlunun geleceği ile alakalı muhtelif bir karar alınmadan önce, borçlunun zor durumda kalmaması için, mahkeme tarafından icra takiplerinin durdurulması gibi bazı zorlayıcı tedbirler alınmaktadır. Alacaklıların hakkı ve borçlunun faaliyetlerini sürdürebilmesi açısından bir denge oluşturulması yönünde Bağımsız Denetim Kuruluşlarına, mahkemelere ve konkordato komiserlerine önemli görevler düşmektedir.

Bağımsız Denetim Kuruluşlarınca hazırlanan raporun “Makul Güvence Veren Denetim Raporu ve Dayanakları” ile konkordato başvurusunu bağımsız denetimden geçmiş, gerçeğe uygun finansal tablolara ve inandırıcı olan zor durumdan çıkış planlarına göre yapılmasına yönelik, taraflar açısından da hakkaniyetli bir prosedür olmasına çalışılmış ve 19 Aralık 2018 tarihli, 7155 Sayılı Kanunla Yayımlanan Abonelik Sözleşmesinden Kaynaklanan Para Alacaklarına İlişkin Takibin Başlatılması Usulü Hakkında Kanun ile İcra ve İflas Kanununun 285 ve 286. maddelerinde değişiklikliğe gidilmiştir.

Ticari hayatın, ülke ekonomisinin fonksiyonlarının yerine getirilmesi için önemi göz önüne alındığında, konkordato ilan eden borçlu firmanın yaşadığı zor sürecin, alacaklı firmanın ticari hayatını çok daha zor hale getirmemesi gerekmektedir. Bu konuda en büyük rolü üstlenen Bağımsız Denetim Kuruluşlarının konkordato talebinde sunulan bilanço, gelir tablosu, nakit akım tablosu, işletmenin devamlılı̆ı esasına göre hazırlanan ara bilançoların, aktiflerin muhtemel satış fiyatı üzerinden hazırlanan ara bilançoların, maddi ve maddi olmayan varlıkların değerini içeren listelerin, tüm alacak ve borçları vadeleri ile birlikte gösteren listelerin, borçlunun mali durumunu açıklayıcı diğer bilgi ve belgelerin başvuru tarihinden itibaren kısa bir süre içerisinde sadece belirli prosedüre göre incelemesi ve sunulan raporların makul güvence verip veremeyeceği Kamu Gözetim Kurumu tarafından da tartışılmaktadır.

Borca batık firmaların ekonomiye kazandırılması yönünde sağlıklı adımlar atılabilmesi, alacaklı firmaları tahsilat aracı olarak aldıkları çeklerin borçlu firmanın konkordato ilan etmesinden sonraki süreci ve Bağımsız Denetim Kuruluşlarınca hazırlanan raporların makul güvence verebilmesi için firmanın nasıl bir denetime tabi tutulması gerektiği incelenmiştir.

\section{IFLAS KAVRAMINA GENEL BAKIŞ}

Iflas, hayatımızın ve özellikle iş dünyasının önemli bir parçasıdır. Gelişen ekonomik piyasalarda alınan riskler sonucu bir tarafın borcunu ödeyemediği zaman iflas prosedürü alacaklıların alacaklarına erişebilmeleri için son çareyi teşkil etmektedir. Arapça dilinde, değerli olmayan bozuk para anlamındaki "fülus" kelimesinden türeyen iflâs; malı tamamen bitme, bozuk paraya bile ihtiyaç duyma anlamına gelmektedir. Bunun yanında bir İslam Hukuku kavramı olarak iflâs, bireyin büyük miktarlarda borçlanıp, bu borçlarını ödeyemez duruma düşmesini ifade etmektedir.

Borca batık olma; 6102 sayılı Türk Ticaret Kanunu 376.maddesine göre Borca batık olma durumu, şirketin aktiflerinin borçlarını karşılayamaması halidir. Borca batık durumda olmanın işaretleri, yıllık ve ara dönem finansal tablolardan, denetime tabi şirketlerde denetim raporlarından, erken teşhis komitesinin raporlarından, yönetim organının belirlemelerinden ortaya çıkabilir. Şirketin borca batık durumda bulunduğu şüphesini uyandıran işaretler varsa, yönetim organı, aktiflerin hem işletmenin devamlılığı esasına göre hem de muhtemel satış fiyatları üzerinden bir ara bilanço çıkartır. Yönetim organı, hem işletmenin devamlılığı esasına hem de aktiflerin muhtemel satış değerlerine göre çıkarılan ara bilânço üzerinden aktiflerin şirket alacaklarını karşılamaya yetmediğine karar vermesi ve gerekli tedbirleri almaması halinde şirketin iflası için mahkemeye başvurur.

Bir hukuk terimi olarak iflâs, ticaret mahkemesi aracılığıyla alınan bir karar sonucunda, borçlu kişinin haczedilebilen bütün mal varlığı üzerinde, iflâs ile ilgili işlemleri yerine getirecek kuruluş tarafından ve alacaklıların alacağının tahsili maksadıyla yapılan kollektif bir cebri icra yolunu anlatmaktadır. Iflâs, hem borçlu kişinin haczedilebilen bütün mal varlığı üzerinde bir etki yaratmakta, hem de borçlunun mal varlığının likidasyonunun bütün alacaklıların menfaati gözetilerek yapılmaktadır. Diğer bir ifadeyle iflâs, gerek alacaklılar bakımından (sübjektif), hem de mal varlığı bakımından (objektif) kollektif bir özellik barındırmaktadır. Bu nedenle, alacaklılardan birinin isteği doğrultusunda hakkında iflâs kararı alınan borçlunun bütün mal varlığı üzerinde, kovuşturma yapmış olsun ya da olmasın, alacaklıların hepsi talep hakkını elinde bulundurmaktadır.

Cebri icra; alacaklılara devlet tarafından verilen haklar ile ve yine devletin bu hususta yetkili makamları aracılığıyla alacağını toplayabilme olanağı sunan hukuksal bir yoldur. Cebri icra cüz'i (ferdi) ve külli (toplu) olmak üzere ikiye ayrılmaktadır. Cüz'i icra; müflisin tek veya birkaç alacaklısının, müflisin mallarından alacaklarını karşılayacak kadar malı haczedip nakite dönüştürerek alacaklarını toplamaya çabaladıkları cebri icra yoludur. Külli icra ise; müflisin karşısında tüm alacaklıların olduğu ve kovuşturmanın konusunu müflisin haczi uygun olan bütün mal ve haklarının meydana getirdiği takip yoludur.

Iflâs hukukunun birinci önceliği, sermayenin korunmasıdır. İflâs hukuku ile hedeflenen, borçlu kişinin mal varlığının likidasyonundan önce, iktisadi ve ticari yaşamın korunması ve sağlıklı bir biçimde işlemesini sağlamaktır. Bu sebeple iflâs hukuku'nun en önemli amacı iflâsın engellenmesi olmuştur. 
Iflâs oluştuğunda mal varlığının likidasyonunu, alacaklılar arasında ayrım yapmadan ve adil bir biçimde yapmak, iflâs hukukunun ikinci amacını oluşturmaktadır. Iflâs tasfiyesi için en uygun olan, gerçekleştirilen likidasyondan alacaklıların alacağının mümkün mertebe hepsini alarak mağduriyetinin giderilmesi, borçlu kişinin ise borçlarından bütünüyle kurtulmasıdır.

\section{IFLASIN HUKUKI SONUÇLARI}

Iflasın hukuki sonuçları; Müflise Etkisi, Alacaklılara Etkisi ve Müflisin Taraf Olduğu Sözleşmelere Etkisi olmak üzere üç başlık altında ele alınmaktadır.

\section{1. iflasın Müflise Etkisi}

iflâsın açılması ile beraber, müflisin (iflas etmiş kişi) haczedilebilen bütün mal ve hakları için bir masa oluşturulmaktadır. Söz konusu bu malların kimin elinde ve kim tarafından kullanıldığının hiçbir değeri olmadığı gibi gerçekten bir araya getirilmesine de lüzum görülmemektedir. İlgili malların masaya dâhil olabilmesi amacıyla bundan başka bir işlem uygulanmamaktadır. Iflas eden kişinin haczedilebilen tüm malları, iflâsın açılması ile birlikte bir nevi özel mal varlığı durumuna dönüşmektedir. Fakat iflâs masasının oluşturulması, iflas eden kişinin masa malları üzerindeki mülkiyet hakkını yitirmesine sebebiyet vermemektedir.

Iflas eden kişinin, alacaklıların alacağını almasını önleyecek veya alacaklıların bazılarına hak etmediği kolaylıkları sağlayan tasarruf işlemleri, alacaklılar arasında adaleti sağlamayı amaçlayan iflâs tasfiyesini yozlaştırmaktadır. Sonuç olarak TBMM'de yasaları dejenere eden bu tip işlemlere karşı alacaklıları korumak amacıyla müflisin tasarruf yetkisine sınırlama koymuştur.

Iflâs, iflas eden kişinin bütün alacaklılarını ilgilendiren bir cebri icra yolu sayıldığından, iflâsın açılmasıyla beraber kişisel icra takiplerine başlanılmasına veya daha önce başlanmış olan takibin sürdürülmesine gerek yoktur. Bu sebeple iflas eden kişiye karşı iflâsın açılmasından önce uygulanmış olan bireysel takipler geçerliliğini yitirmekte ve iflâs kararının kesinleşmesi ile birlikte ortadan kalkmaktadır. Tasfiye işlemleri boyunca,"rehinin paraya çevrilmesi yoluyla takip"hariç olmak üzere, iflas eden kişiye karşı başka bir takip yapılmamaktadır.

Bir başka yönden, iflâsın açılması ile beraber iflas eden kişinin tasarruf yetkisinin sınırlanması, iflas eden bireyin, iflâs masasına girmiş olan mal ve haklara ait hukuk davalarında dava takip hakkını yitirmesine neden olmaktadır.

\section{2.iflasın Alacaklılara Etkisi}

Iflâsın alacaklılar ile alakalı en önemli etkisi, iflas eden kişinin ödeme süresi dolmamış borçlarının, borçludan istenebilecek duruma gelmesinde görülmektedir. Bu durumun nedeni, iflas edenin karşısında alacaklıların bir bölümünün muacccel (vadesi gelmiş), diğer bölümünün müeccel (vadesi gelmemiş) alacağa sahip olması tasfiyede eşitlik prensibine ters düşmektedir. Bunun yanında alacağın muaccel duruma dönüşmesi, masadan elde edilmesini kolaylaştırmaktadır.

Iflâsın alacaklılara bir başka önemli etkisi, içeriği para olmayan alacakların paraya dönüştürülmesinde görülmektedir. Alacaklılar arasında adaleti oluşturmayı hedefleyen bu hüküm ile birlikte, iflas eden kişinin verme, yapma veya yapmama sorumluluğunu üstlendiği durumlarda, bu borçlar paraya çevrilmektedir.

Iflâsın alacaklar ile beraber bu alacaklara ait faizlere de etkisi olmaktadır. İflâsın açılmasıyla beraber, iflâs masasına dâhil olabilecek alacaklar için faiz çalışmaya devam etmektedir. Fakat alacağın tipine göre faiz oranlarında farklılıklar görülmektedir.

\subsection{Müflisin Taraf Olduğu Sözleşmelere Etkisi}

Taraflardan birinin iflâsı durumunda, sözleşme ile hazırlanmış hukukî durumda bir değişiklik olmakta ve sözleşmenin amacı ciddi bir biçimde riske altına girmektedir. Çünkü iflas edenin masa malları üzerinde tasarruf yetkisinin sınırlandırılması, sözleşme ile üstlendiği sorumlulukları gerçekleştirmesini bir hayli zorlaştırmaktadır. Bu zorluk, alacaklı bakımından, ifanın manasını kaybetmesine bile sebep olabilmektedir.

Sözleşme ile düzenlenen şartların sonradan beklenmedik bir biçimde değişikliğe uğraması sonucu, ifanın borçluya üstlenemeyecek derecede zorlaşması ya da alacaklı için bütün manasını kaybetmesi durumlarının hepsine ifa engeli adı verilmektedir. Iflâs belli bir süre için olanaksızık oluşturan bir ifa engeli sayıldığına göre sözleşmeler ile alakalı olarak üç değişik etki yapmaktadır. Bu etkiler, sözleşmenin askıya alınması, müflisin temerrüde düşmesi ve sözleşmenin sona ermesidir.

Iflasın ertelenmesi hükmü sermaye şirketi ya da kooperatifin iflasını önlediğinden, iflas hükmünün ortaya çıkardığı neticeleri doğurmamaktadır. Hükmün etkileri takip hukuku ile alakalı bulunduğundan maddi hukuk dâhilinde bir netice beklenmemektedir. İcra ve İflas Kanunu'nun 179. Maddesinde, sözleşmelerin uygulanması ya da eylemler konusunda her hangi bir düzenleme yapılmamıştır. Kural gereği bir sözleşmeye taraf olanlardan birinin iflası durumunda, sözleşmenin re'sen son bulması söz konusu olmamaktadır. Borçlar Yasası veya Ticaret Yasası gibi değişik yasalarda, iflasın sözleşme üzerindeki etkisi özel bir biçimde düzenlenmişse taraflardan birinin iflası durumunda bu kararlar tatbik edilmektedir. İflas erteleme durumunda yüklenici kuruluş tüzel kişiliğini sürdürdüğünden sözleşmeyle bağılık (ahde vefa: pacta sunt servanda) prensibi geçerliliğini muhafaza etmekte, yüklenici firma ve işveren sözleşmeye uymakta, sözleşmeden kaynaklanan eylemler olduğu gibi sürmektedir. Iflasın ertelenmesi durumu, yüklenici kuruluşun borçlar hukukundan kaynaklanan alacak ve borçlarını etkilememektedir. Taraflar arasında gerçekleşen sözleşme bütün koşulları ile geçerliliğini devam ettirdiğinden kusurlu imalatlar, kusurlu hizmetler ve gecikmeler sebebi ile sözleşme kapsamındaki cezai koşullar geçerliliğini sürdürmektedir. Bu sebeple iflasın ertelenmesi, iflastan değişik olarak biçimleyici bir etkiye sahip olmadığından, önceden gerçekleştirilen sözleşmeleri yok etmediği gibi, sözleşmelerin kapsamını da etkilememektedir. Fakat iflas ertelemedeki yüklenici kuruluşun eser oluşturma borcunu zamanında yerine getirmemesi durumunda alacaklı(işveren) Türk Borçlar Kanunu'nun 473.maddesi gereğince sözleşmeyi feshedebilmektedir. 


\section{IFLASIN ERTELENMESI}

Normal şartlarda bir şirket borçlarını ödeyemez hale gelince iflas eder. İlas kararını mahkeme verir. Iflas eden şirket için iflas masası kurulur, alacakılıar kendilerini buraya kaydettirir, şirket mal varlığı satııır, alacaklılara hisseleri oranında ödeme yapııır. Tüm bu işlemler yapılırken henüz iflas kararı yoktur. Mahkemeye bir iyileştirme planı sunulur ve "iflas erteleme kararı verilmesi halinde bu plan dahilinde şirketin varlığını sürdürebileceği anlamında bir açıklama yapılır. Mahkeme bilirkişi tayin eder ve bu planın gerçek olup olmayacağını araştıır, bir yandan da şirketin yönetimini kayyıma devreder. Bilirkişi mahkemeye rapor verir, plan uygulanırsa ve şirketin sürdürülebileceği anlamına gelen bir rapor sunulursa iflasın ertelenmesine karar verilir. Iflas erteleme; borca batık vaziyette bulunan bir sermaye şirketi ya da kooperatifi belirli yasalar doğrultusunda iflasın olumsuz etkilerinden koruyan bir müessesedir. Bu korumanın gerçekleşmesi; şirketin parasal durumunun düzeltilebilir olması ve şirketin borca batık vaziyetten kurtulması amacıyla zorunlu ve iyileştirici önlemlerin alınması, bu yolla şirketin mevcudiyetini ve çalışmalarını sürdürmesi ile mümkün olmaktadır. İflasın ertelenmesi, şirket muhasebecisinin borca batıklık bilançosunu yönetim kuruluna sunmasından sonra talep ile devam eden, mahkeme aracilığıla talebin uygun bulunması veya kabul edilmemesi ile düzelme veya iflası ile son bulan bir süreçtir.

Iflasın ertelenmesi kurumu, sermaye şirketlerinin veya kooperatiflerin iç yapısı ve mali durumları hakkında herhangi bir bilgisi olmayan alacaklıların, borca batıklık bildirimi üzerine, beklenmedik bir anda gerçekleşen iflas sebebiyle karşı karşıya kalacakları olumsuzluklara karşı korunması ve parasal vaziyetinin iyileşme imkânı bulunan bir sermaye şirketinin veya kooperatifin iflastan çıkarak faaliyetlerine devam etmesi amaçlarına yönelik hizmet yürütmektedir.

\section{IFLAS ERTELEMENIN ŞARTLARI}

Borca batık olduğunu belirleyen sermaye şirketi veya kooperatifin yasa uyarınca öncelikle şirket merkezinin bulunduğu yerdeki Asliye Ticaret Mahkemesi'ne açılacak iflas davasında borca batıklık bildirimini yapması gerekmektedir. Asliye Ticaret Mahkemesi'nin kurulmadığı bölgelerde bu tip davalara bakmakla yetkili mahkeme Asliye Hukuk Mahkemesi'dir. Şayet şirket borca batıklık vaziyetini düzeltebileceğini ve alacaklıların çıkarlarını gözeteceğini düşünüyorsa, iflas davası açarak borca batıklık bildirimini yaptığı mahkemeden iflasın ertelenmesini talep edebilmektedir. İflasın ertelenmesini talep edebilmek için ise, şirketin borca batıklık bilançosunu ve iyileştirme projesini düzenleyerek mahkemeye vermesi zorunludur.

\section{IFLÂSIN ERTELENMESI VE KONKORDATO}

İflâsın ertelenmesi ve konkordato, genel olarak parasal durumu kötüye giden müflislere iflâstan kurtulma olanağı veriyor olsa da her iki kurum birbirlerinden bütünüyle bağımsız ve değişik kurumlardır. Her iki kurum birbirleriyle kıyaslandığında şu konular ortaya çıkmaktadır:

Konkordato, parasal durumu kötü olan müflis ile alacaklıların kanunda belirtilen çoğunluğu arasında bir proje kapsamında uygun görülmüş olan ve borçların tasfiyesi amacına hizmet eden yetkili makamın tasdiki ile sonuç doğuran ve alacaklıların eşit bir şekilde çıkarlarını gözeten kolektif (toplu) bir cebri icra kurumudur. İflâsın ertelenmesi ise, borca batık halde bulunan fakat parasal durumunun düzeltilmesi olanağı bulunan sermaye şirketinin bir iyileştirme projesi kapsamında finansal durumunun düzeltilmesi ve böylelikle iflâstan kurtarılması mahkeme tarafından sağlanan, kendine has özellikler barındıran, geçici bir hukuki korumadır.

Iflâsın ertelenmesi, kuruluşa iyileştirme projesi kapsamında parasal durumunu düzeltebilmesi amacıyla bir zaman verilmesini ve bu süre içinde de parasal durumunun düzeltilmesi için projede bulunan önlemlerin yürütülmesini gerektiren bir kurumdur. Yani iflâsın ertelenmesinde finansal durumunun düzeltilmesinin belli bir usulü bulunmamaktadır. İlâsın ertelenmesinden umulan neticenin gerçekleşmesi maksadıyla zorunlu düzeltme önlemleri bakımndan herhangi bir kısıtlama da söz konusu değildir. Buna karşılık konkordato, yalnızca müflis kuruluşun alacakılırı ile yasada belirtilen usul dahilinde uzlaşması ile gerçekleşmekte ve konkordatonun farklı bir biçimde neticelendirilmesi mümkün olmamaktadır.

Konkordato, iflâsa bağı olsun ya da olmasın her müflise sunulmuş bir imkân iken; iflâsın ertelenmesi, yalnızca sermaye şirketleri ile kooperatiflere sunulmuş bir olanakdır (iik m. 179/1; m. 285/1). iflâsın ertelenmesi parasal durumun kötüye gitmesi durumlarından yalnızca borca batıklık haline mahsus olarak kabul görmüşken; konkordato için finansal durumun kötüye gitmesi halleri bakımından her hangi bir kısıtlama mevzu bahis değildir.

Iflasın ertelenmesi, asliye ticaret mahkemesinden talep edilebilecek bir olanak iken; konkordato sadece icra mahkemesinden talep edilebilmektedir (iik m. 285/1). Yine iflâsın ertelenmesinde istekte bulunanın müflis veya alacaklı olup olmadığı dikkate alınmaksızın kesinlikle iyileştirme projesiyle beraber asliye ticaret mahkemesinde erteleme isteği yaplması mecburi iken; konkordatoda yalnızca müflisin konkordato istemesi halinde, konkordato projesi ile beraber icra mahkemesine istekte bulunulması mecburi olup, konkordatonun alacaklı vasıtasıyla istenmesi halinde ise alacaklının konkordato projesi ile istekte bulunması mecburiyeti bulunmamaktadır (iik m. 285/12).

Ifflâsın ertelenmesinde, konkordatodan değişik olarak, müflis şirketin alacaklılar ile uzlaşmasına gerek görülmediği gibi iyileştirme projesinin alacaklıların belli bir çoğunluğu vasıtasıyla onaylanmasına ve bunun için de alacaklılar toplantısının düzenlenmesine lüzum görülmemektedir. iflâsın ertelenmesi yönteminde, iyileştirme projesinin onaylanabilir olup olmadığına alacaklılar değil, yalnızca gerçekleştirilecek bilirkişi incelemesi neticesinde direkt olarak mahkeme karar vermektedir. Konkordato sürecinde alacaklıların direkt katılımı ve etkisi mevzubahis iken, iflâsın ertelenmesi sürecinde alacaklıların direkt iştirak etmesi söz konusu olmamaktadır. íflâsın ertelenmesinde alacaklılar yalnızca, kayyıma ve mahkemeye danışma mahiyetinde görüş bildirerek erteleme sürecine dahil olabilmektedirler. Bu durum konkordatonun sadece alacaklıların belli bir çoğunluğu aracılığıyla kabul zorunluluğu ile direkt ilişkili olup bu açıdan konkordato sıkı şekil koşullarına bağlı kılınmış bir kurumdur. Bununla birlikte iflâsın ertelenmesinde alacaklıların belli bir çoğunluğunun kabulüne gerek bulunmadığı gibi alacaklıların dinlenilmesi konusu bile mahkemenin değerlendirmesine bırakılmıştır. Ayrıca iflasın ertelenmesinde hâkimin takdir yetkisi bilhassa tanınacak zaman ve tatbik edilecek önlemler bakımından konkordatodan daha geniştir. 
Konkordato, herhangi bir yargılamaya tabi olmadan talep edilebilecek bir olanak iken; iflasın ertelenmesi isteği iflas yargılamasından ayrı olarak tek başına talep edilebilecek bir imkân değildir. Konkordato, görünürde bir iflâs davası olmaksızın talep edilebileceği gibi bir iflâs davası esnasında ve üstelik iflâstan sonra bile istenebilmektedir. Buna karşılık iflâsın ertelenmesi, sadece bir iflâs davası esnasında ve daha iflâs kararı alınmadan önce talep edilebilmektedir.

Her iki kurum kanunda belirtilen zaman aralıkları bakımından da değişiklik göstermektedir. Buna göre konkordato süresi toplam en çok beş ay olabilirken (ïK m. 287/2-6), iflâsın ertelenmesi süresi ise toplam en çok beş sene olabilmektedir (iik m. 179/b-4). Böylelikle iflâsın ertelenmesi, konkordatoya kıyasla daha uzun mühletli ve uygun hukuki bir koruma sağlamaktadır. Bu sebeple iflâsın ertelenmesi, konkordato kurumuna kıyasla uygulamada daha çok tercih edilmektedir.

\section{KONKORDATO VE UZLAŞMA YOLU ILE YENIDEN YAPILANDIRMA}

Uzlaşma yoluyla yeniden yapılandırma, parasal vaziyeti kötüye giden sermaye şirketleri ile kooperatiflerin, alacaklıları ile bir proje doğrultusunda uzlaşarak ticari hayatlarına devam etme imkanı sağlayan bir iyileştirme metodudur. Bu yöntem yalnızca borçların tekrardan düzenlenmesi biçiminde algılanmamalıdır. Çünkü bu yöntemde, şirket veya kooperatifin idaresi ve hukuksal yapısının tekrardan yapılandırılması da söz konusudur. Bu yöntem, her ne kadar İcra İflas Kanununda yer almış olsada, bir külli takip ve tasfiye usulü değil,bir iyileştirme yöntemidir.

Uzlaşma yoluyla yeniden yapılandırma müessesinin temel gayesi, parasal zorluk yaşayan fakat faaliyetlerini sürdürme şansı olan sermaye şirketleri ve kooperatiflerin 5092 sayılı yasayla getirilen usuller doğrultusunda tekrardan düzenlenerek bu sıkıntıdan kurtulmalarının ve çalışmalarını sürdürmelerinin sağlanmasıdır.

Uzlaşma yoluyla yeniden yapılandırma kurumundan faydalanmak amacıyla gerekli bazı şartlar bulunmaktadır. Bunlar (iik md.309/m):

Sermaye şirketi veya kooperatif olma: Yasa yapıcı uzlaşma yoluyla yeniden yapılandırma müessesinden faydalanabilmek için bir sermaye şirketi veya kooperatif olma koşulu getirmiştir. Sermaye şirketi olarak anonim şirket, sermayesi paylara bölünmüş komandit şirket ve limited şirketler uzlaşma yoluyla yeniden yapılandırma isteğinde bulunabilmektedirler (iik md. 309/m) fakat İcra İflas Kanunu'nun madde 309/t'nin ikinci fıkrası ile birlikte sermaye şirketlerinden uzlaşma yoluyla yeniden yapılandırmaya müracaat edebileceklerle alakalı önemli bir kısıtlama mevcuttur. Buna göre banka ve sigorta kurumları uzlaşma yoluyla yeniden yapılandırmaya müracaat edememektedir.

Mali durumun bozulması: Uzlaşma yoluyla yeniden yapılandırma başvurusu yapabilmek amacıyla İcra İflas Kanunu'nun madde 309/m'de açıklanmış olan parasal durumun bozulmasına ilişkin şartlardan birinin meydana gelmesi gerekmektedir. Bunlar:

Aciz Hali: Sermaye şirketi veya kooperatifin ödeme tarihi gelmiş borçlarını verememesi veya borçları ödeme tarihi geldiğinde veremeyecek durumda olduğunun belli olması ile tekrardan yapılandırılmaya gidilmediğinde bu durumun devamlılık arz edebilecek olması halinde, sermaye şirketi ve kooperatif uzlaşma yoluyla yeniden yapılandırma olanağından faydalanabilmektedir (UYYY md.3).

Borca batık olma veya borca batıklık tehlikesi: Uzlaşma yoluyla yeniden yapılandırmaya müracaat edebilmek için şirket veya kooperatifin, borca batık vaziyette bulunması veya borca batık duruma düşme riski taşıması gerekmektedir (iik md. 309/m).

Uzlaşma yoluyla yeniden yapılandırma kurumunda, sermaye şirketi ve kooperatif ilk önce bir yeniden yapılandırma projesi hazırlamaktadır. Söz konusu bu projede, hangi alacaklıların yeniden yapılanma projesinden etkilenip etkilenmeyeceği, projeden etkilenenlere ödemelerin ne miktarda ve hangi şartlar altında yapılacağı, ödemede bulunmak maksadıyla gerekli finansal kaynakların nereden temin edileceği, randıman, karlılık ve parasal durumun düzeltilmesi için örgüt yapısında hangi değişikliklerin uygulanacağı gibi bilgiler yer almaktadır. Uzlaşma yoluyla yeniden yapılandırma kurumunda borçlu sermaye şirketi veya kooperatif, konkordatodaki gibi, alacaklılarına aynı biçimde davranmak mecburiyetinde değildir. Alacaklılardan bir bölümünün tekrardan yapılandırma projesinden hiçbir biçimde etkilenmemesi olanak dâhilindedir. Bunlara alacakları para miktarı ve ödeme tarihi bakımından daha önce tayin edilmiş şartlarla ödeme yapılmaktadır. Yeniden yapılandırma projesinden etkilenmeyen alacaklıların, tekrardan yapılandırma projesi konusunda bilgi verilmesi, tasdiki veya geri çevrilmesi hususunda oylamaya iştirak etmelerine gerek yoktur. Yeniden yapılandırma projesi çerçevesinde alacaklarının miktarında ve ödeme tarihinde değişiklik yapılan alacaklılar, projeden etkilenen alacaklılar biçiminde tanımlanmaktadır. Yeniden yapılandırma projesinden etkilenen alacaklılar da kendi arasında gruplara ayrılmaktadır. Her grup için farklı bir ödeme şekli belirlenebilmektedir fakat yeniden yapılandırma projesinden etkilenen her bir alacaklı grubun, öteki gruptaki alacaklılara yapılan ödeme önerileri konusunda bilgi sahibi yapılması mecburidir. Alacaklıların gruplandırılması hususunda borçlu özgürce hareket edebilmektedir. Ayrıca borçlunun her alacaklıya karşı eşit biçimde muamele etme zorunluluğu vardır. Projeden etkilenen alacaklılara, mektup veya noter vasıtasıyla gerekli bilgilendirmeler yapıldıktan sonra alacaklıların belli bir süre içinde, projeyi onaylayıp onaylamadıklarını gerekli yerlere haber vermesi gerekmektedir.

Projeden etkilenen alacaklılardan bu projeyi kabul edenlerin, bu beyanlarının yer aldığı, imzası ve tarihi noter tarafından tasdiklenmiş tutanağı borçluya ulaştırmaları gerekmektedir. Söz konusu projenin, borçlu tarafından haber verilen süre zarfında kabul edilmemesi halinde, alacaklının projeyi geri çevirdiği varsayılmaktadır. Fakat bu vaziyetteki alacaklılar, projenin kabulüne yönelik lüzum görülen çoğunluğun hesabında nazara alınmamaktadır. Yalnızca projeyi yanıtlayan alacaklılar, projenin kabulü amacıyla lüzum görülen çoğunluğun hesabında dikkate alınmaktadır. Gerçekleştirilen oylama sonucunda projesi kabul gören şirket veya kooperatifin, projenin tasdikini yaptırmak amacıyla asliye ticaret mahkemesine müracaat etmesi gerekmektedir.

Mahkeme, müracaatın ardından 30 gün içerisinde bir duruşma tarihi tayin ederek, projeden etkilenen alacaklılara bunu bildirmektedir. Müracaat tarihi ile mahkemenin son hükmünün verilmesine kadar geçen zaman, ara dönem şeklinde tanımlanmaktadır. Mahkeme, borçlunun veya bir alacaklının istemesi durumunda, ara dönemde, borçlu sermaye şirketi veya kooperatifin mal varlığının muhafaza edilmesi maksadıyla lüzumlu gördüğü önlemleri hemen alma yetkisine sahiptir. Mahkeme bu önlemleri duruşma tarihini beklemeden tayin etmektedir. Mahkeme bu önlem duruşmasında, alacaklılar ve borçlu aracılığıyla belirlenmiş, projenin kabulüne veya geri çevrilmesine ait kararların alınmasına kadar 
geçen süre boyunca bir veya birkaç ara dönem denetçisi göreve getirebilmektedir. Mahkeme, ara dönem denetçisini, borçlunun çalışmalarınışahsen yürütecek veya bu çalışmaları kontrol edecek bir yetkiyle görev başına getirmektedir. Bu ara dönem denetçilerinin yeterli ölçüde bilgi, deneyim ve özelliklere sahip olması gerekmektedir (iik md. 309/ö-II).

Onay duruşmasında en başta borçlu şirket ve kooperatifin sorumluları, alacaklılar ve bulunuyor ise ara dönem denetçisi mahkeme tarafından dinlenmektedir (iik md. 309/p). Mahkeme, borçlunun tekrardan yapılandırmaya iyi niyetli bir biçimde müracaat ettiğini, İcra İflas Kanunu'nun $309 / \mathrm{m}$ ve 309/o maddelerinde belirtilen koşulların gerçekleştiğini ve projeyi geri çevirmiş olan her alacaklının projeyle birlikte elde edecek tutarın en az iflâs tasfiyesi sonunda elde edeceği tutara eşit olduğunu saptadığında müracaatın kabulüne, aksi durumda geri çevrilmesine karar vermektedir. Mahkemenin onay duruşmasının ardından 30 gün içerisinde bir karar alması gerekmektedir. Mahkeme onay kararını alırken, yetkileri yalnızca projenin yürütülmesine ait esasları kontrol edip alacaklılara durumu sistemli bir şekilde raporlamak olan bir veya birkaç proje denetçisi belirleyebilir.

Yeniden yapılandırma projesi, bütün hüküm ve neticelerini, müracaatın kabulüne ait kararın verildiği andan başlayarak doğurmaya başlamaktadır. Projenin şartları, projeden etkilenen alacaklılar ile gerçekleşmiş olan bütün sözleşme hükümlerinden daha önce gelmektedir. Müracaatın onayı isteğinin geri çevrilmesine ait mahkeme kararının alınması durumunda, mahkeme tarafından tanınmış önlemler kalkmakta, dondurulmuş olan dava ve kovuşturmalara kaldığı yerden devam edilmektedir (iik md. 309/r).

Borçlunun projeden meydana gelen sorumluklarını bütünüyle veya bir bölümünü vaktinde yerine getirmemesi durumunda proje denetçisi, projeyi onaylamış olan mahkemeye haber vermektedir. Bu durumda mahkeme, borçlunun mal varlığının muhafaza edilmesi maksadıyla borçlunun mal varlığı ile alakalı bazı önlemler almakta ve bir duruşma tarihi belirleyerek ilanen duyurmaktadır. Mahkeme, borçlunun sorumluluklarının bir bölümünü veya tümüyle gerçekleştirmediğini saptarsa, hemen borçlunun iflâsına karar vermektedir (iik md.309/t).

\section{SONUÇ}

Konkordato, mali açıdan zor duruma düşen borçlunun, içinde bulunduğu sıkıntılı durumdan ticari itibarını sarsmadan korunmasını amaçlayan ve alacaklıları ile yapılan bir anlaşma türüdür. Bu bağlamda, vadesi gelmesine rağmen borçlarını ödemede zorlanan ya da borçlarını vadesinde ödeyememe riski taşıyan bir borçlu, borçları düşürülmek ve belli bir süre tanınmak şartı ile borçlarını ödeyebilmek ya da olası bir iflas yaşamamak için konkordatoya başvurabilir. Bu noktada iflas talebi hakkına haiz olan bütün alacaklıların da konkordato talep hakkı bulunmaktadır. Konkordato işlemleri 7101 Sayılı Kanunla gelen düzenleme öncesi icra mahkemeleri tarafından yürütülürken yeni düzenleme ile bu görev asliye ticaret mahkemelerine devredilmiştir.

Yeni düzenleme ile konkordato talebinde bulunan borçlu, konkordato talebi ile birlikte konkordato ön projesini, mal varlığını içeren belgeleri, alacakılırının listesini, bu proje kapsamında alacaklılara ödenmesi gereken borç tutarını ve iflas etmesi halinde ödeyebileceği tutarı gösteren belgeleri Mahkemeye sunar. Eğer alacaklılar konkordato talebinde bulunursa mahkeme borçluya makul bir süre tanır ve gerekli belgeleri kendisine sunmasını ister. Belgeler hiçbir eksik olmadan mahkemeye sunulduysa, mahkeme borçluya 3 ay geçici bir süre vererek geçici konkordato komiseri görevlendirir. Bu süre en fazla 2 ay daha uzatılabilir. Başka bir ifade ile geçici süre 5 aydan fazla olamaz. Bu noktada geçici sürenin verilmesi, uzatılması ve geçici konkordato komiserinin görevlendirilmesi husundaki kararlar katidir. Geçici sürenin verilmesi ile ilgili karar ticaret sicil gazetesinde yayımlanır. Alacaklılar bu ilamın yayımlanmasından itibaren 7 gün içerisinde kesin sürenin verilmesine ilişkin bir durumun olmadığını beyan ederek konkordato talebinin ret edilmesini talep edebilirler. Mahkeme bu talebi geçici süre içinde değerlendirerek bir karar verir. Mahkemece konkordatonun başarılı olabileceğine kani olunması halinde, borçluya 1 yıl süre ile kesin süre verilir. Kesin sürenin verilmesinden sonra konkordato komiseri tarafından borçluya ait bütün mallar için kıymet takdiri yapılır. Borçluya ait mevcutlar ve kıymeti, alacaklılar toplantısı öncesinde borçluya ve tüm alacaklılara bildirilir ve ilan edilir. Komiser tarafından yapılan bu bildiriden itibaren 15 gün içinde alacaklıların alacaklarını bildirmesi gerekir. Alacaklının alacağını bildirmemesi durumunda ise bilançoya kayıtı olmayacağından konkordato müzakerelerinde de kabul edilmemektedir. Alacaklılar yapılacak olan alacaklılar toplantısında borçlu tarafından sunulan konkordato projesinin kabulü ya da reddi hususunda bir karar sunarlar. Alacaklıların bu projeyi ret etmesi durumunda, mahkeme tarafından resen tasdik yönünde bir karar verilemez. Bu durumda mahkeme, kesin sürenin sona ermesine kadar projeyi onaylayıp onaylamayacağına dair bir karar verir. Konkordato kararının onaylanmaması ve Kanun'da yer alan koşulların gerçekleşmemesi durumunda, Mahkemece borçlunun iflasına karar verilir. Konkordatonun onaylanması durumunda ise borçlu, Projeye uygun bir biçimde faaliyetlerini sürdürür. Konkordatonun yerine getirilmesi amacı ile Mahkeme tarafından yönetim, denetim ve tasfiye tedbirleri almakla görevli bir kayyım atanır. Kayyım bu noktada iki aylık periyotlar halinde projenin akıbeti hakkında mahkemeye rapor verir. Borçlu yada konkordato talebinde bulunan alacaklı, konkordato ile ilgili verilen karar karşısında kararın tebliğ edilmesinden itibaren 10 gün içerisinde istinaf yoluna gidebilir. Bölge Adliye Mahkemesi kararına ilişkin ise yine 10 gün içerisinde temyiz yoluna gidilebilir.

\section{KAYNAKLAR}

Albayrak, Hakan (2007) "iflasın Kaldırılması", Yetkin Yayınları, Ankara.

Altay, S.( 2005). Konkordato ve Yeniden Yapılanma Hukuku, Cilt: 1, İstanbul

Arığlu Osman (2018) "iflas Ertelemenin Kötüye Kullanımı Engellenecek ", http://www.muhasebetr.com/ulusalbasin/haber_oku.php?haber id=20961 Erişim Tarihi: 11.08.2018

Balcı, Şakir (2005) "Sermaye Şirketleri ve Kooperatiflerin Uzlaşma Yoluyla Yeniden Yapılandırılması Hakkında Değerlendirmeler", Manisa Barosu Dergisi, Sayı: 95 (Balcı, Yeniden Yapılandırılma) 
Bektaş, İsmail (2016), "iflas Erteleme",

http://www.istanbulymmo.org.tr/dosyalar/iflas\%20erteleme\%2006.04.2016\%20YMM\%200das\%C4\%B1\%20sunum.pdf, Erişim Tarihi: 15 Mayıs 2018

Kuru, B. (2013) "ícra ve ifflâs Hukuku El Kitabı” (ikinci Baskı), Adalet Yayınevi, Ankara.

Kuru, Baki “Pasifi Aktifinden Fazla Olan Sermaye Şirketlerinin iflâsı”, AD, 1970/10

Milli Gazete (2018) "iflas erteleme kurumunun kaldırılması TBMM'ye sunuldu", https://www.milligazete.com.tr/haber/1495841/iflaserteleme-kurumunun-kaldirilmasi-tbmmye-sunuldu Erişim Tarihi: 11.08.2018

Muşul, Timuçin (2010) "iflasın Ertelenmesi”, i̇stanbul. (Muşul-Erteleme)

Sayın, Uğur (2011) "Türk Hukukunda Mali Yapısı Bozulan Sermaye Şirketleri ve Kooperatiflerde iflasın Ertelemesi”,Yargıtay-Türkiye.

Uyar, Talih (2018). "68 Soruda Konkordato", 9 Eylül Üniversitesi, İzmir.

Uyar, Süleyman, (2019) "Konkordato İşlemine ilişkin Denetim Şirketi Tarafından Hazırlanması Gereken Finansal Analiz ve Bağımsız Denetçi Raporu" http://www.muhasebetr.com/yazarlarimiz/suleyman/030/

Yılmaz, B.B. (2009) "Iflasın Ertelenmesi Talebinde İyileştirme Projesi. Maliye Finans Yazıları", Sayı: 85

Yılmaz, E., (1978) "Olağanüstü Durumlarda Borçlulara Süre Verilmesi ve İcra Takiplerinin Durdurulması”, BATiDER, (1).

Yılmaz, Z. Sanem (2004) "Sermaye Şirketlerinde Geçici Hukuki Korumalar", Güncel Yayınevi, İzmir

Iflas Ertelemenin Şartları, http://www.iflaserteleme.com/iflas-ertelemenin-sartlari/, (17.04.2018)

Oy, O. (2009) “Uzlaşma Yoluyla Yeniden Yapılandırma”, Beta Yayınları, İstanbul

Kamu Gözetim Kurumu, Konkordato Talebine Eklenecek Belgeler Hakkında Yönetmelik Bilgilendirme Toplantısı 